\title{
A chylothorax modern kezelésének bizonyítékalapú áttekintése
}

\author{
Sziklavári Zsolt dr. ${ }^{1}$ - Zsoldos Péter dr. ${ }^{2}$ - Molnár F. Tamás dr. ${ }^{2,3}$ \\ ${ }^{1}$ Klinik für Thoraxchirurgie, Krankenhaus Barmherzige Brüder, Regensburg, Németország \\ ${ }^{2}$ Petz Aladár Megyei Oktató Kórház, Sebészeti Osztály, Mellkassebészet, Győr \\ ${ }^{3}$ Pécsi Tudományegyetem, Általános Orvostudományi Kar, Múveleti Medicina Tanszék, Pécs
}

\begin{abstract}
A chylothorax napjainkban rendszerint mútéti vagy baleseti szövődmény, ritkábban daganat következménye. Prospektív vagy randomizált vizsgálatok hiányában a bizonyítékalapú kezelés személyes tapasztalaton, ideálisan a retrospektív elemzések ismeretében történik. A szerzők célja a chylothorax modern kezelésének áttekintése. A PubMed adatbázist „chylothorax” kulcsszóra szürték az elmúlt tíz év közleményei között, kiemelve az összehasonlító értékeléseket. A módszerek és ajánlások kritikai elemzésekor a szerzók együttes 39 éves klinikai tapasztalatukra támaszkodtak. A konzervatív kezelés sikere az etiológiától függően nagy szórást mutat (3-90\%). A non- és szemi-invazív intervenciós eljárások sikerrátája 50-100\% közötti. Eredménytelen konzervatív kezeléskor a sebészi kezelés, elsősorban a ductus thoracicus lekötése jelenti a standard terápiát. Ezen beavatkozások sikerességi aránya 64-100\% közötti, a morbiditási/mortalitási mutató elérheti a 25\%-ot. A kezelést konzervatívan kell megkezdeni, majd egy lépcsőzetes agresszivitású terápia ajánlott, amelyben a beteg állapota és a drénvolumen irányítják a döntéshozatalt. Az intervenciós radiológiai eljárások biztonságosak, sikeresek és helyet kaptak a konzervatív és mútéti megoldások mellett. Orv. Hetil., 2016, 157(2), 43-51.
\end{abstract}

Kulcsszavak: chylothorax, szövődmény, mellkassebészet

\section{Review of evidence-based modern treatment for chylothorax}

Chylothorax is a multi-factorial complication, frequently of an operation or an accident, but rarely of a tumour. In the absence of prospective or randomised studies evidence-based treatment is normally based on personal experience, ideally in the possession of retrospective analyses using the "best practice" method. The aim of the authors was the review the up-to-date chylothorax treatments. They performed the PubMed database's "chylothorax" keyword search of the publications reported in the last ten years. They put emphasis on articles that included a comparative analysis of the various treatment options. During the critical analysis of the methods and recommendations, the authors relied on their own joint experience amounting to 39 years. The results showed that the success of the initial conservative treatment indicates a significant deviation depending on the etiology (3-90\%). The success rate of noninvasive or semi-invasive interventions is between $50-100 \%$, again depending on the etiology. The standard surgical treatment following an unsuccessful conservative treatment of an operable patient includes the fitting of a (thoracoscopic) knot to the ductus thoracicus, pleurodesis, insertion of a permanent chest drain or a pleuroperitoneal shunt. The success rate of these interventions is between $64-100 \%$, with a morbidity index and mortality index exceeding $25 \%$. Conservative treatment should be the first step, which should then be followed by a gradually increased aggressive therapy, during which the decisions should be made according to the patient's condition and the drain volume. Interventional radiology procedures are safe, successful and they can be offered concurrently with a conservative treatment or operational solutions, although they are available only in a few centres.

Keywords: chylothorax, complication, thoracic surgery

Sziklavári, Zs., Zsoldos, P., Molnár, F. T. [Review of evidence-based modern treatment for chylothorax]. Orv. Hetil., $2016,157(2), 43-51$.

(Beérkezett: 2015. szeptember 29.; elfogadva: 2015. október 22.) 


\section{Rövidítések:}

ChTX = chylothorax MCT = Medicum-Chain-Triglyceride; TIPS $=$ transjugularis intrahepaticus portoszisztémás sönt

Chylothorax (ChTX) alatt a pleura két lemeze között felgyülemlő nyirkot értjük, amely folyadék - többek között - gazdag kilomikronban, valamint trigliceridben. Bármely életkorban jelentkezhet, és számos ok idézheti elő. Felnőttkorban alapvetően négy etiológiai csoport különíthető el: trauma vagy tumor okozta, idiopathiás és kevert kórképü ChTX. Leggyakrabban oesophagectomia (4\%-os előfordulással) [1] vagy szívmútét után (4-6\%-os előfordulással) figyelhető meg $[2,3]$. Tüdőrákmútét során végzett mediastinalis lymphadectomia nyomán 0,26-3\%-ban lép fel ChTX [4]. Ha a folyamat nem uralható vagy krónikussá válik, a malnutritio és az immunológiai komplikációk miatt 50\%-os mortalitással is lehet számolni [5]. A ChTX kezelési lehetőségei jelenleg a konzervatív, sebészi és - legújabban - az intervenciós radiológiai, illetve radiációs eljárások.

Az 1633 óta Bartolet által először leírt [6], de az irodalomban 1976-ig csupán 390 közölt eset kórképi ritkasága miatt nem állnak rendelkezésre prospektív vizsgálatok a kezelés legsikeresebb módjáról vagy időtartamáról. Iránytűként az eddig közölt „legjobb gyakorlat” (best practice) cikkek kritikus elemzése szolgálhat.

\section{A ductus thoracicus anatómiája}

A ductus thoracicus a mellkasban futó fó nyirokértörzs, amely 2-3 mm vastagságú. A test alsó feléből és a hasüregből származó nyirok a cysterna chyliben egyesül a bélrendszerből származó chylusszal, az aortaárkádon lép át a rekeszen (ligamentum arcuatum medianum), az oesophagus jobb oldalán fut felfelé, a thoracalis 5. csigolya magasságában keresztezi azt, végül az angulus venosumban ömlik a bal oldalon a vena brachiocephalica sinistrába [7]. Számtalan variáció, kollaterális és vénás kapcsolódási pont jellemzi. Ez magyarázza a hátulsó mediastinumban a nyirokelvezető út mentén végzett mútétek során a sérülés kockázatát és a ChTX esetenkénti oldaliságát is.

\section{Kórélettan}

A ductus thoracicus sérülésekor a kiáramló nyirok vagy helyileg összegyưlik és később tör be a pleuraürbe, vagy közvetlenül az utóbbiba folyik egy már fennálló pleuralis résen (például mútét által okozott) keresztül. A ChTX ritkán, de kialakulhat transdiaphragmaticus áramlás következtében, chylosus ascites esetén is. A kórkép megjelenése általában jobb oldali [8]. Éhomi állapotban az óránkénti nyirokvezetés körülbelül $15 \mathrm{ml}$-es, amely érték postprandialisan $100 \mathrm{ml}$-re növekedik $[9,10]$. A ductus thoracicus sérülése tehát gyorsan vezethet nagy volumenû folyadékgyülem képződéséhez.

\section{Kóroki megoszlás}

Etiológiájuk alapján traumás, nem traumás és idiopathiás $[2,4]$ formákat különítünk el; a relatív gyakoriságuk betegpopulációnként változik.

Napjainkban a leggyakoribb traumás ok a mellkasi mútét lett, így például az oesophagusreszekció, amely az esetek mintegy 3-4\%-ában vezet chylothoraxhoz [1]. Prediszponáló tényező a radikális mediastinalis lymphadenectomia, a mediastinalis ( $\mathrm{pN} 2$ ) nyirokcsomók metasztázisai és a Da Vinci-robottal véghezvitt nyirokcsomó-dissectio [11]. A tüdőreszekció mértéke (lobectomia vs. bilobectomia vs. pneumectomia) nem játszik bizonyítottan döntő szerepet az incidencia alakulásában [4]. Nem tisztázott továbbá a neoadjuváns, különösen az irradiáció prediktív értéke sem a ChTX kialakulásában; Pancoast-tumoros betegek esetében, neoadjuváns kezelést és mútétet követően, a ChTX-incidencia nem haladta meg a már ismertetett világirodalmi átlagot [12].

Nem traumás chylothorax esetén a nyirokrendszer szivárgása lehet közvetlen beszúrődés vagy kompresszió eredménye. Relatív gátolt áramlás fordulhat elő, ha fokozott a nyiroktermelés, például emelkedett centrális vénás nyomású vagy portalis hypertensióban/májcirrhosisban szenvedő betegeknél [13].

Veleszületett chylothorax esetén (előfordulási gyakoriság: 1:20 000 terhesség) a lehetséges okok a szülési sérülés vagy a nyirokerek rendellenessége [14]. Általánosságban a chylothorax igen ritka kórkép gyermekeknél [15].

\section{Klinikai megjelenés}

Mellkasi csővel nem rendelkező betegek esetében a kis volumenú vagy szubakut chylothorax klinikailag nem különbözik más mellkasi folyadékgyülemektől. A nagy volumenú vagy fóként a gyorsan kialakuló chylothorax térfoglaló hatásokat idézhet elő, így nehézlégzést, köhögést, mellkasi fájdalmat és hypovolaemiát. Mivel a nyirok önmagában nem okoz gyulladásos irritációt és bakterosztatikus, pleuralis jellegü fájdalom és láz nincs [16].

Röntgen-, CT- és ultrahangfelvételen a chylothorax képe nem specifikus, általában egyoldali pleularis folyadékgyülemként jelenik meg (1. ábra). Típusosan thoracocentesissel opálos, tejszerú folyadék nyerhető belőle, de ez csak az esetek felében látható $[17,18]$. Éhgyomrú betegek (például a peri- vagy posztoperatív) vagy veleszületett chylothorax esetén a folyadékgyülem serosusnak vagy tisztának is tünhet, sérülés után pedig vérrel festenyzett lehet, így nem kelt feltünést. Zavaros lehet a folyadék pleuralis empyema vagy úgynevezett pseudochylothorax esetén is, de az elkülönítés laborkémiai vizsgálatokkal ( $\mathrm{pH}$, glükóz, laktátdehidrogenáz - LDH) és Gram-festéssel egyszerû [19]. Gyanút kelt ChTX-re az egyébként megmagyarázhatatlan mellkasi folyadékgyülem, vagy mütét után a normális táplálásra visszatérő betegnél a pleuralis drénen keresztül ürített folyadék menynyiségének kifejezett növekedése [20]. 


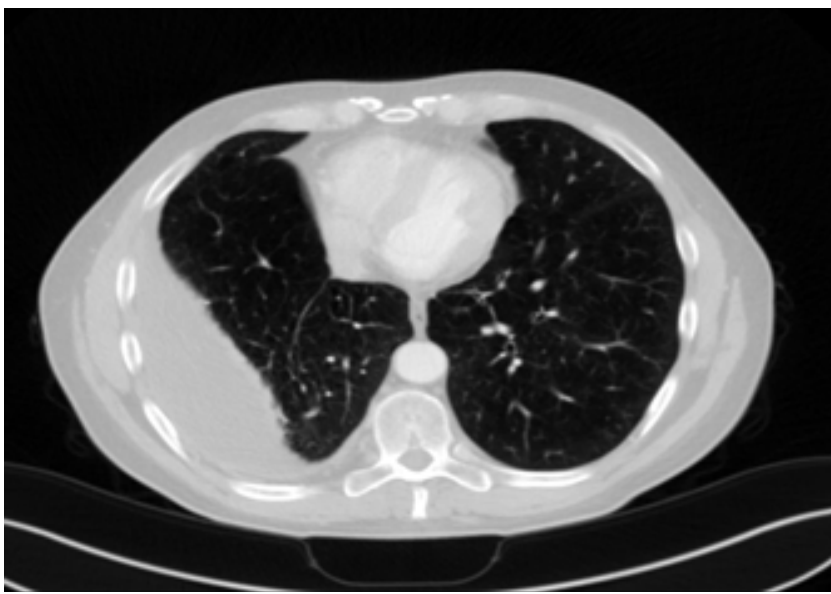

1. ábra

Jobb oldali nem specifikus folyadékgyülem (ChTX) torakoszkópiát és nyirokcsomó-biopsziát követően

\section{Diagnosztikus laboratóriumi tesztek}

A diagnózis felállításához nem elegendő a folyadékgyülem „tejszerú” makroszkópos megítélése (2. ábra) [18]. A chylothorax eseteinek többsége exsudatív jellegú, de az esetek körülbelül 15\%-ában transsudativ is lehet. A transsudativ folyadékgyülem más, például lymphomát, amyloidosist, hepaticus (portalis hypertensio/cirrhosis) vagy kardiális etiológiát jelez [1, 17-21].

A biztosabb diagnózis felállításához szükséges a kilomikronok jelenlétének kimutatása. Ezek a körülbelül 0,5-1,0 $\mu \mathrm{m}$ méretű, fehérjékből és lipidekből (hosszú láncú trigliceridek) álló jellegzetes részecskék elektroforézissel vagy Sudan III festéssel láthatóvá tehetôek [l, 21].

Ha a lipoproteinelemzés nem lehetséges a kilomikronok kimutatására, a trigliceridek és koleszterin mennyiségének meghatározása is hasznos lehet [22, 23].

Staats és mtsai szerint chylothorax esetén a betegek 99\%-ánál az aspirátum trigliceridtartalma $>110 \mathrm{mg} / \mathrm{dl}$ és koleszterintartalma $<200 \mathrm{mg} / \mathrm{dl}$, míg a $<50 \mathrm{mg} / \mathrm{dl}$ trigliceridkoncentráció 95\%-os valószínúséggel kizárja a chylothoraxot. Amennyiben a trigliceridszint $50 \mathrm{mg} / \mathrm{dl}$ és $110 \mathrm{mg} / \mathrm{dl}$ közötti, szükséges lehet a folyadék lipoprotein-elektroforézisének elvégzése [18].

Figyelembe kell venni ugyanakkor a beteg általános és tápláltsági állapotát is. Maldonado és mtsai felhívták a figyelmet arra, hogy a betegeik 14\%-ánál (mind rossz állapotú beteg) a trigliceridszint $110 \mathrm{mg} / \mathrm{dl}$ alatti volt [17]

A pseudochylothoraxot, amely szintén tejszerü, $>200$ $\mathrm{mg} / \mathrm{dl}$ koleszterinkoncentráció és alacsony trigliceridkoncentráció $(<110 \mathrm{mg} / \mathrm{dl})$ jellemzi (koleszterin:triglicerid arány $>1)$. Ilyen esetekben tuberkulózisra vagy rheumatoid pleuritisre lehet gondolni $[1,20]$.

A valódi chylothorax ezek szerint típusos esetben egy lymphocytapredomináns exsudatív folyadék alacsony LDH-szinttel és emelkedett koleszterin/triglicerid koncentrációval.

\section{Kórlefolyás}

A chylothorax egy olyan volumenhiányos állapot, amelyben a beteg folyamatosan tekintélyes mennyiségü zsírt és zsírban oldódó vitamint, fehérjéket, elektrolitokat, immunoglobulinokat és T-lymphocytákat veszít, amely malnutritióhoz, testsúlyvesztéshez és károsodott immunrendszerhez vezethet $[20,24]$. A külső nyirokelvezetés következtében kialakuló akár csak 8 napos T-sejtdepléció a septikaemia kockázatának teszi ki a betegeket [25].

Ha a chylothorax daganattal áll összefüggésben, az alapbetegség befolyásolja a prognózist. Kezeletlen chylothorax esetén a betegek körülbelül $50 \%$-a halhat meg a szövődmények miatt $[1,4,26]$. Ha a chylothorax posztoperatívan jelentkezik, az alapmútét 30 napos mortalitása az ötszörösére emelkedik [27].

\section{Kezelési lehetőségek}

A módszerek sokszínúsége, a közlemények eltérő konklúziói nemcsak a kórforma többarcúságát, az eltérő fázisok, háttértényezők különbségeit és a terápiás módszerek több mint fél évszázados változásait tükrözik [28], hanem bizonyos mértékben a chylothorax Grál-kelyhe iránti folyamatos - és eredménytelen - keresést is.

\section{Megelözés}

A posztoperatív chylothorax, mint a szövődmények legtöbbje, elkerülhetetlen, legfeljebb felléptük gyakorisága csökkenthető. Guo és mtsai például a VATS-eosophagusreszekció során végzett - profilaktikus - ductusligatúrával igyekeznek a ChTX-et elkerülni [29]. Jelenleg azonban nincsenek használható szakmai ajánlások sem a nyirokcsomó-dissectióval, sem egyéb más, intraoperatív manőverrel kapcsolatosan [4].

\section{Konzervatí kezelés}

Amennyiben a napi mellkasi folyadékvesztés mértéke $1000 \mathrm{ml}$ alatti, általában a primer konzervatív kezelést javasolják, de csak korlátozott ideig, és sikertelensége esetén az invazívabb kezelést kell követni $[1,4,30]$.

Sarokkövek a kielégítő folyadék- és elektrolitpótlás mellett a megfelelő táplálás (diéta). Ismételt thoracocentesist általában csak akkor végeznek, ha az alapbetegség rövid távú kezelésétól javulást várnak vagy a klinikai tünetek kis foka csak időnkénti aspirációt igényel. Nagy volumenú vagy különösen a már szimptómás chylothorax esetén a folyamatos drenálásnak kell következnie [19, $22,31]$.

A kezdeti konzervatív kezelés részeként csökkenteni kell a nyirokáramlást a ductus thoracicuson keresztül abban bízva, hogy a nyirokszivárgás spontán megszúnik. Elő́ŕrható közepes láncú triglicerid (medium-chain triglyceride - MCT) tartalmú étrend, így a triglicerid köz- 


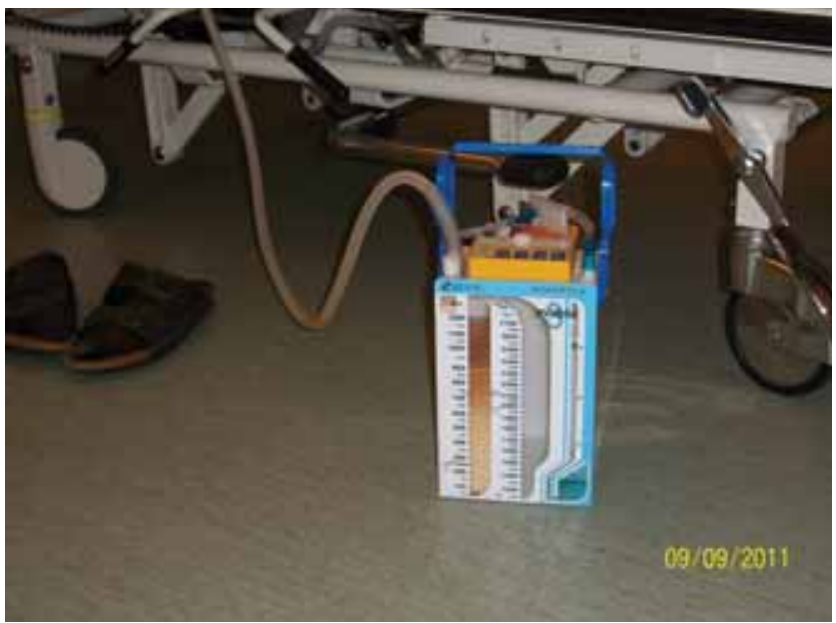

2. ábra

Nagy volumenú chylosus folyadékvesztés mellkasi csövön ke-
resztül

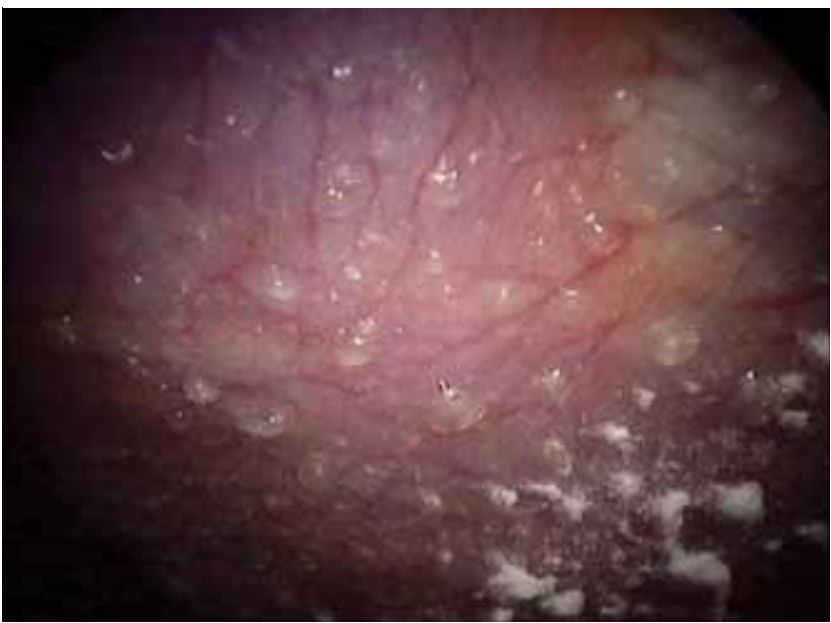

3. ábra

Talkumos pleurodesist követő azonnali kémiai pleuritis, amely a kívánt pleurodesishez vezethet

vetlenül a portalis vénás rendszerben szívódik fel anélkül, hogy bejutna az intestinalis vénás rendszerbe és ezáltal a ductus thoracicusba. Drasztikusabb eljárás a totális gyümölcs-zöldség diéta, illetve a nil per os-parenteralis táplálás mellett $[4,22]$. Ezek az eljárások önmagukban és az esetek többségében nem sikeresek (sikerráta 23-52\%). Ezért sok helyen a diéta csupán része a komplex kezelésnek (1. táblázat) [5, 11, 32-37].

A diéta mellett ismert a nyirokáramlás további csökkentése szomatosztatin- vagy analóg octreotidszerekkel [38-42]. Azonban sem a chylothoraxot, mint javallatot, sem a gyógyszer dózisát, módszerét és időtartamát nem határozták még meg, illetve nem standardizálták prospektív vizsgálatokban. Bryant és mtsai szerint, ha a drénen ürült volumen napi mennyisége 500 ml-nél kevesebb lesz a kiegészítő subcutan szomatosztatin adásától számított 48 órán belül, az arra utal, hogy a kezelés effektív, a beteget MCT-diétáztatni lehet. További 48 órá- val később és $500 \mathrm{ml} /$ nap alatti folyadékvesztésnél a mellkasi cső eltávolítható $[11,43]$.

Ha a chylothorax nem traumás eredetú, az alapbetegség kezelése (kemoterápia, besugárzás) javuláshoz vezethet, de a sikerességi arány így is csak 0-tól 30\%-ig terjed [44-46]. Ha a nyirokszivárgás közvetlenül daganatos vagy lymphomás beszűrődés eredménye, nem várható, hogy csupán a nyirokáramlás sebességének csökkentésével elő lehet idézni javulást [44].

A sugárterápia az inguinalis nyirokfolyás mint szövődmény elfogadott kezelési alternatívája [47]. Posztoperatív (traumás) chylothorax esetén a mediastinalis besugárzást (analóg módon) 2011-ben kis esetszámon sikeres adjuváns kezelésként mutattuk be (100\%-os sikerráta) [4].

Általánosságban, a konzervatív kezelés sikerességi aránya 2,5\%-tól több mint 75\%-ig terjed (1. táblázat); ugyanakkor $1000 \mathrm{ml} /$ nap feletti kimeneti mennyiség esetén a konzervatív kezelés sikerességi aránya alacsony $[1,4,30,32]$.

Ha a drénvezetés jelentősen csökken konzervatív kezelés hatására, javasolt a terápia állandósítása néhány hétig fenntartott szigorú MCT- vagy zöldség-gyümölcs diéta mellett [22, 48, 49].

1. táblázat | A konzervatív kezelés eredményei chylothorax esetén

\begin{tabular}{|c|c|c|c|c|}
\hline $\begin{array}{l}\text { Chylothorax kezelése } \\
\text { felnőttkorban }\end{array}$ & Szerző (év) & Etiológia & $\begin{array}{l}\text { Eset- } \\
\text { szám }\end{array}$ & $\begin{array}{l}\text { Siker- } \\
\text { ráta }\end{array}$ \\
\hline \multicolumn{5}{|l|}{ Konzervativ kezelés } \\
\hline $\begin{array}{l}\text { Diéta/parenteralis } \\
\text { táplálás }\end{array}$ & $\begin{array}{l}\text { Zabeck, } 2011 \\
{[32]}\end{array}$ & Posztoperatív & 37 & $32 \%$ \\
\hline $\begin{array}{l}\text { Diéta/parenteralis } \\
\text { táplálás }\end{array}$ & $\begin{array}{l}\text { Zabeck, } 2011 \\
{[32]}\end{array}$ & Nem traumás & 45 & $2,5 \%$ \\
\hline $\begin{array}{l}\text { Diéta/parenteralis } \\
\text { táplálás }\end{array}$ & $\begin{array}{l}\text { Chalvet du } \\
\text { Rieu, } 2011 \\
{[5]}\end{array}$ & Posztoperatív & n. a. & $70 \%$ \\
\hline $\begin{array}{l}\text { Parenteralis } \\
\text { táplálás/ } \\
\text { szomatosztatin sc. }\end{array}$ & $\begin{array}{l}\text { Bryant, } 2014 \\
{[11]}\end{array}$ & Posztoperatív & 48 & $90 \%$ \\
\hline $\begin{array}{l}\text { Diéta/parenteralis } \\
\text { táplálás }\end{array}$ & $\begin{array}{l}\text { Cerfolio, } \\
1996[33]\end{array}$ & Posztoperatív & 47 & $28 \%$ \\
\hline Parenteralis táplálás & $\begin{array}{l}\text { Shimizu, } \\
2002[34]\end{array}$ & Posztoperatív & 26 & $23 \%$ \\
\hline $\begin{array}{l}\text { Diéta/octrerotid } \\
\text { sc. }\end{array}$ & $\begin{array}{l}\text { Fujita, } 2014 \\
{[35]}\end{array}$ & Posztoperatív & 15 & $87 \%$ \\
\hline Parenteralis táplálás & $\begin{array}{l}\text { Cho, } 2014 \\
{[36]}\end{array}$ & Posztoperatív & 46 & $52 \%$ \\
\hline Diéta & $\begin{array}{l}\text { Cho, } 2014 \\
{[36]}\end{array}$ & Posztoperatív & 21 & $48 \%$ \\
\hline Diéta & $\begin{array}{l}\text { Maldonado, } \\
2010 \text { [37] }\end{array}$ & Traumás & 35 & $49 \%$ \\
\hline Diéta & $\begin{array}{l}\text { Maldonado, } \\
2010[37]\end{array}$ & Nem traumás & 21 & $24 \%$ \\
\hline
\end{tabular}




\section{Intervenciós kezelés}

A nyirokszivárgás pontos helyét csak akkor érdemes meghatározni, ha az befolyásolja a kezelést [4]. A képalkotás megtörténhet nem invazív módszerrel, például radionuklidokkal vagy mágneses rezonanciás vizsgálattal $[50,51]$. A diagnosztikus MRI úgynevezett fluidérzékeny szekvenciákat használ (a mágneses rezonanciás cholangiopancreatographiához hasonlóan). A pontossága a szivárgás helyének meghatározása tekintetében megbízhatóbb a radionuklid képalkotással szemben és hasznos lehet az intervenciós eljárás tervezésében. A lymphographia szintén kimutathatja a szivárgást, de mivel ez egy ritkán végzett invazív beavatkozás, manapság kevés helyen kérhető [18].

A diéta mellett lehetôség van a chylothoraxot szemiinvazívan, intervenciós eljárásokkal is visszaszorítani, például a pleura lemezeinek összetapasztásával, amely akkor történik, ha a pleuraürbe kémiai anyagokat (talkum, jód, tetracyclin, bleomycin) juttatva pleuritist váltunk ki, amelynek következtében a pleura lemezei egymáshoz ta-

2. táblázat |Az intervenciós eljárások eredményei chylothorax esetén

\begin{tabular}{|c|c|c|c|c|}
\hline $\begin{array}{l}\text { Chylothorax kezelése } \\
\text { felnóttkorban }\end{array}$ & Szerző (év) & Etiológia & $\begin{array}{l}\text { Eset- } \\
\text { szám }\end{array}$ & $\begin{array}{l}\text { Siker- } \\
\text { ráta }\end{array}$ \\
\hline \multicolumn{5}{|l|}{ Intervenció tipusa } \\
\hline $\begin{array}{l}\text { Percutan } \\
\text { embolisatio vagy } \\
\text { interruptio }\end{array}$ & Itkin, 2010 [53] & $\begin{array}{l}\text { Traumás } \\
\text { (p.o.) }\end{array}$ & 109 & $71 \%$ \\
\hline $\begin{array}{l}\text { Pleurodesis } \\
\text { (talkum) }\end{array}$ & Akin, 2012 [54] & $\begin{array}{l}\text { Traumás } \\
\text { (p. o.) }\end{array}$ & 26 & $73 \%$ \\
\hline $\begin{array}{l}\text { Pleurodesis } \\
\text { (talkum) }\end{array}$ & Paul, 2009 [55] & $\begin{array}{l}\text { Traumás } \\
\text { (p.o.) }\end{array}$ & 6 & $83 \%$ \\
\hline $\begin{array}{l}\text { Pleurodesis } \\
(\text { OK-432) }\end{array}$ & $\begin{array}{l}\text { Shimizu, } 2002 \\
{[34]}\end{array}$ & $\begin{array}{l}\text { Traumás } \\
\text { (p. o.) }\end{array}$ & 15 & $87 \%$ \\
\hline $\begin{array}{l}\text { Direkt } \\
\text { lymphangiographia }\end{array}$ & $\begin{array}{l}\text { Schoellnast, } 2011 \\
{[56]}\end{array}$ & $\begin{array}{l}\text { Traumás } \\
\text { (p. o.) }\end{array}$ & 2 & $50 \%$ \\
\hline $\begin{array}{l}\text { Direkt } \\
\text { lymphangiographia }\end{array}$ & $\begin{array}{l}\text { Alejandre-Lafont, } \\
2011 \text { [57] }\end{array}$ & Traumás & 43 & $51 \%$ \\
\hline $\begin{array}{l}\text { Percutan } \\
\text { embolisatio }\end{array}$ & Cope, $1999[58]$ & $\begin{array}{l}\text { Traumás } \\
\text { (p. o.) }\end{array}$ & 11 & $18 \%$ \\
\hline $\begin{array}{l}\text { Pleurodesis } \\
(\text { OK-432) }\end{array}$ & Takuwa, 2013 [8] & $\begin{array}{l}\text { Traumás } \\
\text { (p. o.) }\end{array}$ & 37 & $84 \%$ \\
\hline $\begin{array}{l}\text { Percutan } \\
\text { embolisatio vagy } \\
\text { interruptio }\end{array}$ & Cope, 2002 [59] & $\begin{array}{l}\text { Traumás } \\
\text { (p.o.) }\end{array}$ & 42 & $74 \%$ \\
\hline $\begin{array}{l}\text { Percutan } \\
\text { embolisatio vagy } \\
\text { interruptio }\end{array}$ & $\begin{array}{l}\text { Nadolski, } 2013 \\
{[60]}\end{array}$ & $\begin{array}{l}\text { Nem } \\
\text { traumás }\end{array}$ & 34 & $53 \%$ \\
\hline $\begin{array}{l}\text { Percutan } \\
\text { embolisatio vagy } \\
\text { interruptio }\end{array}$ & Boffa, $2008[61]$ & $\begin{array}{l}\text { Traumás } \\
\text { (p.o.) }\end{array}$ & 37 & $57 \%$ \\
\hline Irradiáció & $\begin{array}{l}\text { Sziklavári, } 2013 \\
{[4]}\end{array}$ & $\begin{array}{l}\text { Traumás } \\
\text { (p. o.) }\end{array}$ & 7 & $100 \%$ \\
\hline Diéta/pleurodesis & Cho, $2014[36]$ & $\begin{array}{l}\text { Traumás } \\
\text { (p. o.) }\end{array}$ & 27 & $100 \%$ \\
\hline
\end{tabular}

padnak (3. ábra). A pleurodesis akkor is kezelési lehetôség, ha a chylothorax oka rosszindulatú daganat, így akkor is alkalmazzuk, ha a daganat kezelése nem hozott elegendő javulást vagy a mútéti út nem járható akár funkcionális, akár technikai okból. Ugyanakkor a pleurodesis csak teljesen kitágulni képes tüdővel rendelkező betegeknél lehet sikeres (úgynevezett non-trapped tüdő esetén) [32]. A pleurodesis sikerrátája 71-100\% közötti (2. táblázat), de 15\%-os komplikációs rátával kell számolni $[34,49]$.

Hepaticus chylothorax esetén a portalis vénás nyomás és így a nyirokáramlás is csökkenthető transjugularis intrahepaticus portoszisztémás sönt (TIPS) segítségével [52].

Számos non- vagy szemi-invazív radiológiai kezelés is alkalmazható traumás és nem traumás chylothorax esetén egyaránt (2. táblázat) $[4,8,34,36,53-61]$, bár zömük néhány központra korlátozódik [62].

Diagnosztikus lymphographia után a chylothorax „spontán” gyógyulását az esetek felében figyelték meg $[57,60]$. Ugyanakkor a lymphographia kezelési sikere nehezen értékelhető, mert az esetek egyötödében nem is lehet kivitelezni, valamint $500 \mathrm{ml}$ napi nyirokvesztés felett az esetek kétharmadában hatástalan.

A nyirokszivárgás közvetlen elzárása megpróbálható szövetragasztó célzott, például CT-irányított beadásával [63], de ezekkel az eljárásokkal kapcsolatban nem rendelkezünk sok tapasztalattal.

Sokkal több tapasztalat áll rendelkezésre a ductus thoracicus percutan embolisatiójával kapcsolatban, amely a ductus thoracicus lekötésének alternatívájaként végezhető felnőtteknél és gyerekeknél egyaránt [53, 59].

A cysterna chyli és a ductus thoracicus megfestése rendszerint a láb nyirokútjai felól történik, de a lipiodol injekció beadható egy inguinalis nyirokcsomóba is $[9$, $53,59,60,63]$. A cysterna chyli megfestése után a cysterna percutan kanülálása egy vékony túvel történik, majd egy mikrokatéteren keresztül elvégezhetô a sérülés helyén a coiling.

$\mathrm{Az}$ anatómiai variánsok nagy száma miatt a betegek 30\%-a nem rendelkezik cisterna chylivel vagy punkcióra alkalmas nyirokérrel $[59,64]$. Ha a kanülálás nem kivitelezhető, megkísérelhető a lymphographiával már azonosított nyirokutak „megkarcolása” („tûs megszakítás”, interruptio) és ezáltal a nyirokáramlás csökkentése [9, $59,65]$. Az így kezelt betegek körülbelül egyharmadánál ez a szivárgás megszúnéséhez vezet $[59,64]$, az esetleges abdominalis chylus pedig felszívódik.

Ha sikeresen kanülálják a ductus thoracicust, az embolisatio az esetek több mint 90\%-ában sikeres $[53,59]$. A percutan embolisatio azoknál a betegeknél is gyógyulást hozhat, akiknél sikertelen volt a mútéti intervenció $[9,53]$.

A ductus thoracius embolisatiójának klinikai sikere az alapbetegségtôl függ; a sikerességi arány alacsonyabb nem traumás chylothorax (52\%-os siker) $[52,66]$ esetén, mint traumás esetekben (60\%) [60]. A 3\% körüli szövőd- 
3. táblázat |A sebészi eredmények chylothorax esetén

\begin{tabular}{|c|c|c|c|c|}
\hline $\begin{array}{l}\text { Chylothorax kezelése } \\
\text { felnőttkorban }\end{array}$ & Szerző (év) & Etiológia & $\begin{array}{l}\text { Eset- } \\
\text { szám }\end{array}$ & $\begin{array}{l}\text { Siker- } \\
\text { ráta }\end{array}$ \\
\hline \multicolumn{5}{|l|}{ Sebészi kezelés } \\
\hline $\begin{array}{l}\text { Thoracic duct } \\
\text { ligation }\end{array}$ & $\begin{array}{l}\text { Paul, } 2009 \\
{[55]}\end{array}$ & Traumás & 19 & $95 \%$ \\
\hline $\begin{array}{l}\text { Thoracic duct } \\
\text { ligation }\end{array}$ & $\begin{array}{l}\text { Cerfolio, } \\
1996[33]\end{array}$ & Traumás & 32 & $94 \%$ \\
\hline $\begin{array}{l}\text { Thoracic duct } \\
\text { ligation }\end{array}$ & $\begin{array}{l}\text { Akin, } 2012 \\
{[54]}\end{array}$ & Traumás & 7 & $100 \%$ \\
\hline $\begin{array}{l}\text { Thoracic duct } \\
\text { ligation }\end{array}$ & $\begin{array}{l}\text { Shimizu, } \\
2002[34]\end{array}$ & Traumás & 5 & $100 \%$ \\
\hline PleurX katéter & $\begin{array}{l}\text { DePew, } \\
2013[31]\end{array}$ & Nem traumás & 8 & $64 \%$ \\
\hline
\end{tabular}

ményaránnyal és ez idáig nulla mortalitással a percutan ductus thoracicus embolisatio viszonylag biztonságos eljárásnak számít $[9,63]$. Egy hosszú távú vizsgálatban krónikus lábduzzadást figyeltek meg a betegek 7\%-ánál és krónikus hasmenést a betegek körülbelül 12\%-ánál. Az, hogy ezek az eredmények az eljárás következményei-e, jelenleg még nem ismertek [67].

\section{Sebészi kezelés}

Ha a konzervatív terápia nem vezetett gyógyuláshoz, sokáig a mútét volt az egyetlen kezelési módszer, amely a chylothorax mortalitási arányát 50\%-ról akár 0\%-ra csökkentheti $[33,35,59,68]$. A sebészi lehetőségeket és az eredményeket a 3. táblázat [31-34, 54, 55] foglalja össze.

A mútéti intervenció általában a ductus thoracicus lekötését foglalja magában, de végezhető mưtéti pleurodesis és lehetséges az adott mellkasfél állandó drenálása.

A ductus thoracicus (adott esetben torakoszkópos) lekötése - amely a traumás chylothorax esetén a leginkább alkalmazott eljárás - általában a T8 és T12 csigolyák között, a jobb oldali rekeszizom felett történik. A lekötés után a nyirok a nyirokkollaterálisokon és a lymphovénás anasztomózisokon keresztül drenálódik. Zabeck és mtsai szerint traumás chylothorax esetén a mütéti intervenciónak $900 \mathrm{ml}$ napi nyirokveszteség mellett haladéktalanul meg kell történie, ugyanis ilyen esetekben a konzervatív terápia hatástalan [32]. A sebészi kezelés legnagyobb nehézsége a ductus thoracicus vagy a szivárgás azonosítása. Ezért gyakran tejszínt (4. ábra) vagy metilénkékkel festett tejfölt adnak be a betegnek mütét előtt közvetlenül vagy közben, gyomorszondán keresztül. Ha a ductus továbbra sem azonosítható, a ductus vélt helyén úgynevezett mass-ligationt (a szövetek tömeges lekötése) végzünk [30, 66]. Ezen sebészi kezelés értékéből levon, hogy az esetek 11\%-ában újabb komplikáció lép föl, illetve, hogy 9\%-ban chylothoraxrecidíva jelentkezhet [4], és a halálozási arány akár a 25\%-ot is elérheti [69].
Ha a mütét nem eredményes, vagy ha a ductus thoracicus lekötése nem megvalósítható, a sebészi (torakoszkópos) pleurodesis (4. ábra) megszüntetheti a chylothoraxot $[1,30,33,70]$. A talkumpleurodesis sikerrátája 73-83\% közötti $[54,55]$. A sebészi pleurodesis akkor is kezelési lehetőség, ha a chylothorax oka rosszindulatú daganat. Akkor alkalmazzák, ha a daganat kezelése nem hozott elegendő javulást, vagy ha úgy vélik, hogy a ductus thoracicus megszakítása nem megvalósítható. A maradéktalan tüdőtágulás itt is feltétel [71]. A lymphovénás anasztomózisok képzése nem vált terápiává [70].

Utolsó sebészi lehetőségként pleuroperitonealis sönt vagy állandó drenázs (5. ábra) képzése megfelelő „alagutas" katéterrendszer behelyezésével megfontolható $[31,72]$.

Minimális megterhelést jelent a beteg számára a pleuraûrbe adott fibrinragasztó alkalmazása, jelenleg azonban kevés esetszám áll rendelkezésre [73].

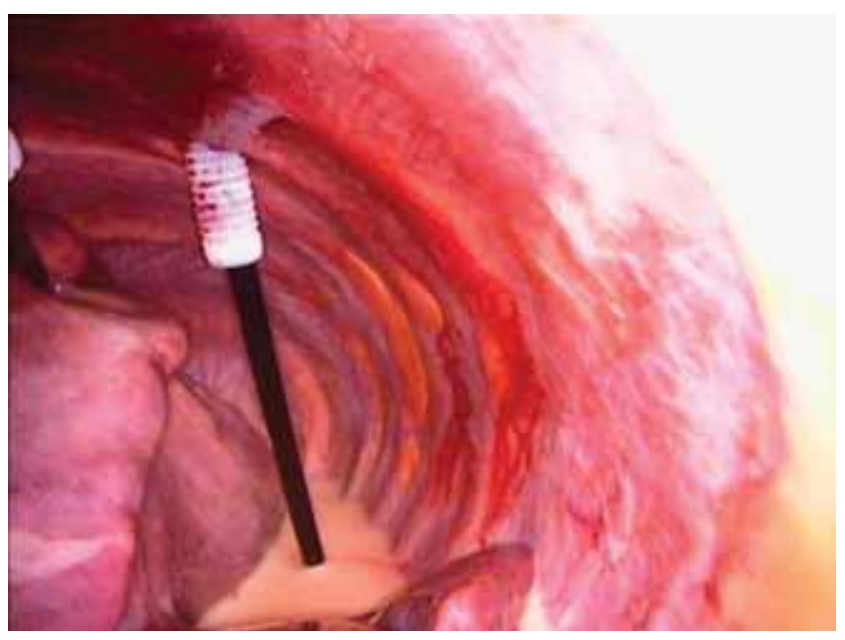

4. ábra ba adott tejszínes stimulálást követően

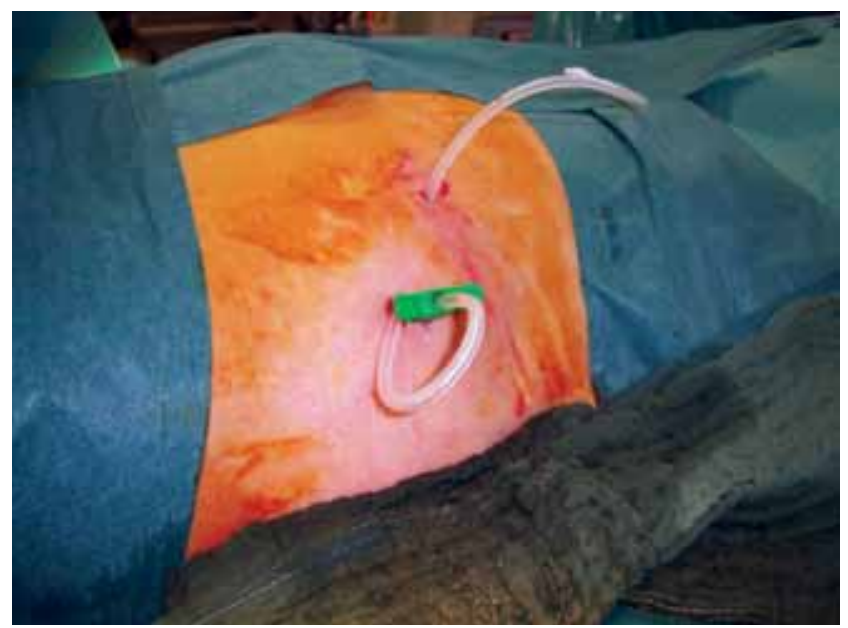

5. ábra $\quad$ Bőr alá implantált állandó mellkasi (PleurX) katéter 
A felgyülemlett sebészi tapasztalat alapján a mútéti kezelést a következő négy esetben javasolják, bár az útmutatások nélkülözik a kontrollált vizsgálatok eredményeit.

1. A napi nyirokveszteség több mint $1000 \mathrm{ml}$ (gyermekeknél ez a küszöb >100 ml/ttkg).

2. Maximum 14 kezelési napon át a drénen ürített napi mennyiség 500-1000 ml közötti.

3. A drénen ürített mennyiség változatlan 2 hét után is.

4. Klinikai rosszabbodás történik például alultápláltság vagy anyagcserezavarok esetén.

\section{Következtetések}

A chylothorax terápiáját minden esetben diétával kell megkezdeni. Szükségszerű továbbá a mellkasfél becsövezése is; egyrészről azért, hogy a folyadékvesztést detektálhassuk, másrészről azért, hogy a tüdő maximálisan kitáguljon.

A kezdeti konzervatív kezelés (például parenteralis táplálás vagy speciális étrend) az esetek 20-80\%-ában sikeres. Az eljárás még eredményesebb, ha szomatosztatin adásával kombinálják.

$\mathrm{Az}$ intervenciós radiológiai kezelések, mint a percutan ductus thoracicus embolisatio vagy a nyirokerek percutan roncsolása az esetek körülbelül 70\%-ában sikeres és az esetek akár 80\%-ában gyógyuláshoz vezet, még sikertelen mütét után is. A percutan módszerek utáni szövődmények aránya 3\%-os. Az intervenciós radiológiai eljárások tehát biztonságosak és helyet kaptak a konzervatív kezelés, illetve a mútéti megoldások mellett a chylothorax kezelésében.

Ha a kezelés nem eredményes, vagy ha a napi nyirokveszteség több mint 11 , jelenleg a sebészi beavatkozás - mint a ductus thoracicus lekötése, pleurodesis vagy pleuroperitonealis sönt - jelenti a standard terápiát. Az intervenció torakoszkóposan is végezhető.

Ezen beavatkozások sikerességi aránya 25-95\% közötti. A beavatkozásokon átesett betegek többsége súlyos állapotú, a halálozási arány 25\%-os is lehet.

A számos adat tükrében a fejlődés számottevő, azonban a legjobb döntés továbbra is individuális marad, ahol fó szempont a beteg teherbíró képessége, az etiológia, a lépcsőzetesen fokozódó invazivitású módszerek alkalmazása, a türelem és nem utolsósorban az adott helyen rendelkezésre álló tapasztalat és orvosi technológia.

Anyagi támogatás: A szerzők a közlemény megírásához, illetve a kapcsolódó kutatómunkához anyagi támogatásban nem részesültek.

Szerzői munkamegosztás: Zs. P.: Kutatómunka. Sz. Zs.: Az anyag strukturálása. M. F. T.: A kézirat megszövegezése. A cikk végleges változatát mindhárom szerző elolvasta és jóváhagyta.

Érdekeltségek: A szerzőknek nincsenek érdekeltségeik.

\section{Irodalom}

[1] McGrath, E. E., Blades, Z., Anderson, P. B.: Chylothorax: aetiology, diagnosis and therapeutic options. Respir. Med., 2010, 104(1), $1-8$.

[2] Doerr, C. H., Allen, M. S., Nichols, F. C. 3rd, et al.: Etiology of chylothorax in 203 patients. Mayo Clin. Proc., 2005, 80(7), 867-870.

[3] Narayan, P., Rabaman, N., Molnar, T. F., et al.: Chylothorax following cardiac surgery caused by unusual lymphatic anatomy. Asian Cardiovasc. Thorac. Ann., 2007, 15(5), e58-e59.

[4] Sziklavari, Z., Allgäner, M., Hübner, G., et al.: Radiotherapy in the treatment of postoperative chylothorax. J. Cardiothorac. Surg., 2013, 8, 72 .

[5] Chalret du Rieu, M., Baulieux, J., Rode, A., et al.: Management of postoperative chylothorax. J. Visc. Surg., 2011, 148(5), e346e352.

[6] Kaul, T. K., Bain, W. H., Turner, M. A., et al.: Chylothorax: report of a case complicating ductus ligation through a median sternotomy, and review. Thorax, 1976, 31(5), 610-616.

[7] Phang, K., Bowman, M., Phillips, A., et al.: Review of thoracic duct anatomical variations and clinical implications. Clin. Anat., 2014, 27(4), 637-644.

[8] Takuwa, T., Yoshida, J., Ono, S., et al.: Low-fat diet management strategy for chylothorax after pulmonary resection and lymph node dissection for primary lung cancer. J. Thorac. Cardiovasc. Surg., 2013, 146(3), 571-574.

[9] Chen, E., Itkin, M.: Thoracic duct embolization for chylous leaks. Semin. Intervent. Radiol., 2011, 28(1), 63-74.

[10] Lyon, S., Mott, N., Koukounaras, J., et al.: Role of interventional radiology in the management of chylothorax: a review of the current management of high output chylothorax. Cardiovasc. Intervent. Radiol., 2013, 36(3), 599-607.

[11] Bryant, A. S., Minnich, D. J., Wei, B., et al.: The incidence and management of postoperative chylothorax after pulmonary resection and thoracic mediastinal lymph node dissection. Ann. Thorac. Surg., 2014, 98(1), 232-235.

[12] Kunitoh, H., Kato, H., Tsuboi, M., et al.: Phase II trial of preoperative chemoradiotherapy followed by surgical resection in patients with superior sulcus non-small-cell lung cancers: report of Japan Clinical Oncology Group trial 9806. J. Clin. Oncol., 2008, 26(4), 644-649.

[13] Light, R. W.: Pleural effusions. Med. Clin. North Am., 2011, 95(6), 1055-1070.

[14] Rustico, M. A., Lanna, M., Coviello, D., et al.: Fetal pleural effusion. Prenat. Diagn., 2007, 27(9), 793-799.

[15] Yekeler, E., Ulutas, $H .:$ Bilateral chylothorax after severe vomiting in a child. Ann. Thorac. Surg., 2012, 94(1), e21-e23.

[16] Miller, J. I. Jr:: Anatomy of the thoracic duct and chylothorax. In: Shields, T. W., LoCicero, J. 3rd, Ponn, R. B., et al. (eds.): General thoracic surgery. 6th ed. Lippincott Williams \& Wilkins, Philadelphia, 2005, 879-888.

[17] Staats, B. A., Ellefson, R. D., Budabn, L. L., et al.: The lipoprotein profile of chylous and nonchylous pleural effusions. Mayo Clin. Proc., 1980, 55(11), 700-704.

[18] Maldonado, F., Hawkins, F. J., Daniels, C. E., et al.: Pleural fluid characteristics of chylothorax. Mayo Clin. Proc., 2009, 84(2), 129-133.

[19] Sassoon, C. S., Light, R. W.: Chylothorax and pseudochylothorax. Clin. Chest Med., 1985, 6(1), 163-171.

[20] Skouras, V., Kalomenidis, I.: Chylothorax: diagnostic approach. Curr. Opin. Pulm. Med., 2010, 16(4), 387-393.

[21] Huggins, J. T.: Chylothorax and cholesterol pleural effusion. Semin. Respir. Crit. Care Med., 2010, 31(6), 743-750.

[22] Benedix, F., Lippert, H., Meyer, F.: Etiology, diagnosis and treatment of lymphocutaneous fistulas, chylascites and chylothorax as infrequent but serious complications following surgical procedures. Zentralbl. Chir., 2012, 137(6), 580-586. 
[23] Sziklavari, Z., Neu, R., Hofmann, H. S., et al.: Persistent pleural effusion following thoracic surgery. Chirurg, 2015, 86(5), 432436.

[24] Wasmuth-Pietzuch, A., Hansmann, M., Bartmann, P., et al.: Congenital chylothorax: lymphopenia and high risk of neonatal infections. Acta Paediatr., 2004, 93(2), 220-224.

[25] Breaux, J., Marks, C.: Chylothorax causing reversible T-cell depletion. J. Trauma, 1988, 28(5), 705-707.

[26] Hölscher, A. H., Fetzner, U. K., Bludau, M., et al.: Complications and management of complications in oesophageal surgery. Zentralbl. Chir., 2011, 136(3), 213-223.

[27] Shah, R. D., Luketich, J. D., Schuchert, M. J., et al.: Postesophagectomy chylothorax: Incidence, risk factors, and outcomes. Ann. Thorac. Surg., 2012, 93(3), 897-904.

[28] Bessone, L. N., Ferguson, T. B., Burford, T. H.: Chylothorax. Ann. Thorac. Surg., 1971, 12(5), 527-550.

[29] Guo, W., Zhao, Y. P., Jiang, Y. G., et al.: Prevention of postoperative chylothorax with thoracic duct ligation during video-assisted thoracoscopic esophagectomy for cancer. Surg. Endosc., 2012, 26(5), 1332-1336.

[30] Nair, S. K., Petko, M., Hayward, M. P.: Aetiology and management of chylothorax in adults. Eur. J. Cardiothorac. Surg., 2007 $32(2), 362-369$.

[31] DePew, Z. S., Iqbal, S., Mullon, J. J., et al.: The role for tunneled indwelling pleural catheters in patients with persistent benign chylothorax. Am. J. Med. Sci., 2013, 346(5), 349-352.

[32] Zabeck, H., Muley, T., Dienemann, H., et al.: Management of chylothorax in adults: when is surgery indicated? Thorac. Cardiovasc. Surg., 2011, 59(4), 243-246.

[33] Cerfolio, R. J., Allen, M. S., Deschamps, C., et al.: Postoperative chylothorax. J. Thorac. Cariovasc. Surg., 1996, 112(5), 13611365.

[34] Shimizu, K., Yoshida, J., Nishimura, M., et al.: Treatment strategy for chylothorax after pulmonary resection and lymph node dissection for lung cancer. J. Thorac. Cardiovasc. Surg., 2002, 124(3), 499-502.

[35] Fujita, T., Daiko, H.: Efficacy and predictor of octreotide treatment for postoperative chylothorax after thoracic esophagectomy. World J. Surg., 2014, 38(8), 2039-2045.

[36] Cho, H. J., Kim, D. K., Lee, G. D., et al.: Chylothorax complicating pulmonary resection for lung cancer: effective management and pleurodesis. Ann. Thorac. Surg., 2014, 97(2), 408-413.

[37] Maldonado, F., Cartin-Ceba, R., Hawkins, F. J., et al.: Medical and surgical management of chylothorax and associated out comes. Am. J. Med. Sci., 2010, 339(4), 314-318.

[38] Das, A., Shah, P. S.: Octreotide for the treatment of chylothorax in neonates. Cochrane Database Syst. Rev., 2010, 8(9), CD006388.

[39] Bello, S. O., Rahamim, J.: High-dose intravenous octreotide is safe and may be superior to surgery in managing severe postesophagectomy chylothorax in high-risk patients. Ann. Thorac. Surg., 2015, 100(1), 297-299.

[40] Cannizzaro, V., Frey, B., Bernet-Buettiker, V.: The role of somatostatin in the treatment of persistent chylothorax in children. Eur. J. Cardiothorac. Surg., 2006, 30(1), 49-53.

[41] Roebr, C. C., Jung, A., Proquitté, H., et al.: Somatostatin or octreotide as treatment options for chylothorax in young children: a systematic review. Intensive Care Med., 2006, 32(5), 650-657.

[42] Sharkey, A. J., Rao, J. N.: The successful use of octreotide in the treatment of traumatic chylothorax. Tex. Heart Inst. J., 2012, $39(3), 428-430$.

[43] Lim, K. A., Kim, S. H., Huh, J., et al.: Somatostatin for postoperative chylothorax after surgery for children with congenital heart disease. J. Korean Med. Sci., 2005, 20(6), 947-951

[44] O'Callaghan, A. M., Mead, G. M.: Chylothorax in lymphoma: mechanisms and management. Ann. Oncol., 1995, 6(6), 603607.
[45] Teng, C. L., Li, K. W., Yu, J. T., et al.: Malignancy-associated chylothorax: a 20-year study of 18 patients from a single institution. Eur. J. Cancer Care, 2012, 21(5), 599-605.

[46] Larsen, S., Manoharan, A., Fermanis, G., et al.: An unusual case of chylothorax complicating non-Hodgkin's lymphoma. Leuk. Lymphoma, 2000, 38(1-2), 207-209.

[47] Dietl, B., Pfister, K., Aufschläger, C., et al.: Radiotherapy of inguinal lymphorrhea after vascular surgery. A retrospective analysis. Strahlenther. Onkol., 2005, 181(6), 396-400.

[48] Gómez-Caro, A. A., Moradiellos Diez, F. J., Marrón, C. F., et al.: Conservative management of postsurgical chylothorax with octreotide. Asian Cardiovasc. Thorac. Ann., 2005, 13(3), 222224.

[49] Collard, J. M., Laterre, P. F., Boemer, F., et al.: Conservative treatment of postsurgical lymphatic leaks with somatostatin-14 Chest, 2000, 117(3), 902-905.

[50] Pui, M. H., Yueh, T. C.: Lymphoscintigraphy in chyluria, chyloperitoneum and chylothorax. J. Nucl. Med., 1998, 39(7), 12921296.

[51] Yu, D. X., Ma, X. X., Wang, Q., et al.: Morphological changes of the thoracic duct and accessory lymphatic channels in patients with chylothorax: detection with unenhanced magnetic resonance imaging. Eur. Radiol., 2013, 23(3), 702-711.

[52] Lutz, P., Strunk, H., Schild, H. H., et al.: Transjugular intrahepatic portosystemic shunt in refractory chylothorax due to liver cirrhosis. World J. Gastroenterol., 2013, 19(7), 1140-1142.

[53] Itkin, M., Kucharczuk, J. C., Kwak, A., et al.: Nonoperative thoracic duct embolization for traumatic thoracic duct leak: experience in 109 patients. J. Thorac. Cardiovasc. Surg., 2010, 139(3), 584-589.

[54] Akin, H., Olcmen, A., Isgorucu, O., et al.: Approach to patients with chylothorax complicating pulmonary resection. Thorac. Cardiovasc. Surg., 2012, 60(2), 135-139.

[55] Paul, S., Altorki, N. K., Port, J. L., et al.: Surgical management of chylothorax. Thorac. Cardiovasc. Surg., 2009, 57(4), 226-228.

[56] Schoellnast, H., Maybody, M. Getrajdman, G. I., et al.: Computed tomography-guided access to the cisterna chyli: introduction of a technique for direct lymphangiography to evaluate and treat chylothorax. Cardiovasc. Intervent. Radiol., 2011, 34(Suppl. 2), S240-S244.

[57] Alejandre-Lafont, E., Krompiec, C., Rau, W. S., et al.: Effectiveness of therapeutic lymphography on lymphatic leakage. Acta Radiol., 2011, 52(3), 305-311.

[58] Cope, C., Salem, R., Kaiser, L. R.: Management of chylothorax by percutaneous catheterization and embolization of the thoracic duct: prospective trial. J. Vasc. Interv. Radiol., 1999, 10(9), 1248-1254.

[59] Cope, C., Kaiser, L.: Management of unremitting chylothorax by percutaneous embolization and blockage of retroperitoneal lymphatic vessels in 42 patients. J. Vasc. Interv. Radiol., 2002, 13(11), 1139-1148

[60] Nadolski, G. J., Itkin, M.: Thoracic duct embolization for nontraumatic chylous effusion: experience in 34 patients. Chest, 2013, 143(1), 158-163.

[61] Boffa, D. J., Sands, M. J., Rice, T. W., et al.: A critical evaluation of a percutaneous diagnostic and treatment strategy for chylothorax after thoracic surgery. Eur. J. Cardiothorac. Surg., 2008, $33(3), 435-439$.

[62] Lee, E. W., Shin, J. H., Ko, H. K., et al.: Lymphangiography to treat postoperative lymphatic leakage: a technical review. Korean J. Radiol., 2014, 15(6), 724-732.

[63] Gaba, R. C., Owens, C. A., Bui, J. T., et al.: Chylous ascites: a rare complication of thoracic duct embolization for chylothorax. Cardiovasc. Intervent. Radiol., 2011, 34(2), 245-249.

[64] Binkert, C. A., Yucel, K., Davison, B. D., et al.: Percutaneous treatment of high-output chylothorax with embolization or needle disruption technique. J. Vasc. Interv. Radiol., 2005, 16(9), 1257-1262. 
[65] Litherland, B., Given, M., Lyon, S.: Percutaneous radiological management of high output chylothorax with CT-guided needle disruption. J. Med. Imaging Radiat. Oncol., 2008, 52(2), 164167.

[66] Bölïkbas, S., Kudelin, N., Dönges, T., et al.: Therapy management of chylothorax. Chirurg, 2010,81(3), 255-263.

[67] Laslett, D., Trerotola, S. C., Itkin, M.: Delayed complications following technically successful thoracic duct embolization. J. Vasc. Interv. Radiol., 2012, 23(1), 76-79.

[68] Orringer, M. B., Bluett, M., Deeb, G. M.: Aggressive treatment of chylothorax complicating transhiatal esophagectomy without thoracotomy. Surgery, 1988, 104(4), 720-726.

[69] Alexiou, C., Watson, M., Beggs, D., et al.: Chylothorax following oesophagogastrectomy for malignant disease. Eur. J. Cardiothorac. Surg., 1998, 14(5), 460-466.

[70] Ryu, J. H., Tomassetti, S., Maldonado, F.: Update on uncommon pleural effusions. Respirology, 2011, 16(2), 238-243.
[71] Sabn, S. A.: Management of malignant pleural effusions. Monaldi Arch. Chest Dis., 2001, 56(5), 394-399.

[72] Gupta, D., Ross, K., Piacentino, V. 3rd, et al.: Use of LeVeen pleuroperitoneal shunt for refractory high-volume chylothorax. Ann. Thorac. Surg., 2004, 78(1), e9-el2.

[73] Akaogi, E., Mitsui, K., Sohara, Y., et al.: Treatment of postoperative chylothorax with intrapleural fibrin glue. Ann. Thorac. Surg., 1989, 48(1), 116-118.

(Sziklavári Zsolt dr., Föhrenstrasse 5., Pettendorf, 93186, Németország e-mail: sziklavari_zsolt@yahoo.com)

\section{Tisztelt Szerzőink, Olvasóink!}

Az Orvosi Hetilapban megjelenő/megjelent közlemények elérhetöségére több lehetőség kínálkozik.

Rendelhető különlenyomat, melynek áráról bővebben a www.akkrt.hu honlapon (Folyóirat Szerzőknek, Különlenyomat menüpont alatt) vagy Szerkesztöségünkben tájékozódhatnak.

A közlemények megvásárolhatók pdf-formátumban is, illetve igényelhető Optional Open Article (www.oopenart.com).

Adott dij ellenében az online közlemények bárki számára hozzáférhetök honlapunkon (a közlemények külön linket kapnak, így más oldalról is linkelhetővé válnak).

Bővebb információ a hirdetes@akkrt.hu címen vagy különlenyomat rendelése esetén a Szerkesztöségtöl kérhető. 